\title{
Content of information exchanged by emergency room nurses during shift handover
}

Teor da informação partilhada entre enfermeiros durante a passagem de turno no serviço de urgência

Contenido de la información compartida entre enfermeros durante el cambio de turno en el servicio de urgencias

Joâo Sousa*(D); Dina Meneses**(D); Dúlia Alves***(D); Lisete Machado****(D); Fernanda Príncipe ${ }^{* * * * *(D)}$;

Liliana Mota ${ }^{* * * * * *}$ (D)

\section{Abstract}

Background: The importance of sharing information in the continuity of care is acknowledged, and it is a challenge for nurses to decide which information must be exchanged.

Objective: To understand the content of the information exchanged by nurses during shift handover in the emergency room. Methodology: A qualitative, exploratory study using focus group as a method for data collection, involving 13 nurses acknowledged by their peers as emergency experts.

Results: From the analysis of the transcripts 4 categories emerged (Patient information, Health status development, Type of communication and Constraints of the shift handover), which demonstrate the content of the information shared by nurses in the emergency room.

Conclusion: Nurses are made aware of the importance of shared information during shift handover, acknowledging that this information can be substantially improved. In order to accomplish that, information about patient identification, current health status, relevant information, medical history, type of care provided, and care plan should be shared during the shift handover.

Keywords: information management; patient handoff; emergency service, hospital; continuity of patient care; nurses

\section{Resumo}

Enquadramento: É reconhecida a importância da partilha de informaçáo na continuidade dos cuidados, sendo um desafio para os enfermeiros a decisão sobre qual a informação a partilhar.

Objetivo: Compreender o teor da informaçâao partilhada pelos enfermeiros durante a passagem do turno, no serviço de urgência.

Metodologia: Estudo qualitativo, exploratório, com recurso ao focus group como método de recolha de dados, tendo participado 13 enfermeiros reconhecidos pelos seus pares como peritos em urgência.

Resultados: Após a análise das transcrições emergiram 4 categorias (Informação relativa ao cliente; Evoluçáo do estado de saúde; Tipo de comunicação e Fatores condicionantes da passagem de turno), que demonstram o teor da informação partilhada entre os enfermeiros no servico de urgência.

Conclusáo: Os enfermeiros estáo sensibilizados para a importância da informaçáo partilhada durante a passagem de turno, tendo consciência que esta pode ser substancialmente melhorada. Para tal, durante a passagem de turno deve ser partilhada informação sobre identificação do cliente, situação atual, informaçóes pertinentes, antecedentes de saúde, cuidados prestados e plano de cuidados.

Palavras-chave: gestão da informação; transferência da responsabilidade pelo paciente; serviço hospitalar de emergência; continuidade da assistência ao paciente; enfermeiras e enfermeiros

*BSc., Nurse Specialist in Medical-Surgical Nursing, Hospital de Santo Espírito da Ilha Terceira, 9700-049, Angra do Heroísmo, Portugal [joaoestevessousa@msn.com]. (1) https://
orcid.org/0000-0001-6153-5330. Contribution to the article: bibliographical research, data collection and analysis, discussion of results, and writing of the article. Address for correspondence: Rua dos Lourais n. 27-D, 9760-662, Praia da Vitória, Portugal.

**BSc., Nurse Specialist in Medical-Surgical Nursing, Hospital de Santo Espírito da Ilha Terceira, 9700-049, Angra do Heró́smo, Portugal [meneses.dina@amail.com]. (D) https://orcid.org/0000-0002-1926-8993. Contribution to the article: bibliographical research data collection and analysis, discussion of results, and writing of the article

***BSc., Nurse Specialist in Medical-Surgical Nursing, Hospital de Santo Espírito da Ilha Terceira, 9700-049, Angra do Heroismo, Portuga [dulialves@ hotmail.com]. D tps://orcid.org/ $0000-0003-2231-7511$. Contribution to the article: bibliograp
ch. data collection and analysis, discussion of results, and writing of the article. *. data collection and analysis, discussion of results, and writing of the article. Terceira, $9700-049$. Angra do Heroísmo, Portugal "lisete machado $a$ hotmail.com?. (1D htps://orcid.org/0000-0001-6741-6519. Contribution to the article: bibliographical research, data collection and analysis, discussion of results, and writing of the article

******Ph.D., Adjunct Professor at the Higher School of Health North of the Portuguese Red Cross, [vice.presidente@essnortecvp.pt. 3720-126, Oliveira de Azeméis, Portugal [fernandaprincipe@esenfcvpoa.eu].(D) https://orcid.org/0000-0002-1142-3258. Contribution to the article: data analysis, discussion of results, and writing of the article.

******Ph.D. Adjunct Professor at the Higher School of Health North of the Portuguese Red Cross, 3720-126, Oliveira de Azemeis, Portugal lilianamota@esenfcypoa.eu..(D htof results, and overall article revision

\section{Resumen}

Marco contextual: Se reconoce la importancia de compartir la información en la continuidad de la atención, y los enfermeros se enfrentan al reto de decidir qué información compartir.

Objetivo: Comprender el contenido de la información compartida por los enfermeros durante el cambio de turno en el servicio de urgencias.

Metodología: Estudio cualitativo y exploratorio, para el cual se utilizó el grupo focal como método de recogida de datos, con la participación de 13 enfermeros reconocidos por sus pares como expertos en urgencias.

Resultados: Tras el análisis de las transcripciones, surgieron 4 categorías (Información relacionada con el paciente; Evolución del estado de salud; Tipo de comunicación y Factores que afectan al cambio de turno), que demuestran el contenido de la información compartida entre los enfermeros del servicio de urgencias.

Conclusión: Los enfermeros son conscientes de la importancia de la información compartida durante el turno, y saben que puede mejorarse sustancialmente. Con este fin, durante el cambio de turno, se debe compartir información sobre la identificación del paciente, la situación actual, la información relevante, los antecedentes médicos, la atención prestada y el plan de atención.

Palabras clave: gestión de la información; pase de guardia; servicio de urgencia en hospital; continuidad de la atención al paciente; enfermeros 


\section{Introduction}

Nursing is a science that is constantly evolving, in which the need for care and the delivery of such care are increasingly complex, requiring excellence in nursing practice, providing evidence-based care which results in a reasoned decision.

In their daily practice, nurses exchange information permanently, transferring the responsibility of caring for patients from one nurse to the other. This information is perceived as the driver of continuous care, which reinforces the importance of knowing the content of information produced by nurses, to perfect it and contribute to the continuous improvement of the quality of care provided (Mota, 2010). As a science based on human interaction, nursing involves a remarkable wealth of information. Therefore, it is crucial to analyze the content of this information (Pereira, 2009).

The continuity of care has significant importance in the dynamics of nursing care since it is the core of the assessment processes of the quality of health services. In this way, it is associated with the quality of the patient information exchanged, the continuous improvement of the quality of care provided (Mota, Pereira, \& Sousa, 2014).

One of the main objectives of the shift handover is to promote the quality and continuity of care in a safe way. The emergency service is a unique service, where the constant activity is conducive to the occurrence of interruptions, which can result in communication gaps.

The efficient change of shift is associated with improved quality of care. Therefore, identifying what constitutes an effective shift handover style for reducing the number of adverse events resulting from an incomplete shift change is paramount (Smeulers, Tellingen, Lucas, \& Vermeules, 2012).

Patient safety is one of the pillars of the quality of health care, so communication gaps during shift handover can have harmful consequences for the patient, due both to the omission of data and inconsistency in such data. The Joint Commission International (World Health Organization, 2007) warns that the main cause of nursing events is communication gaps. According to Friesen, White, and Byers (2008), an ineffective change of shift can lead to gaps in the delivery of patient care and hence jeopardize the safety of patients.

The main objective of this study is to understand the content of the information shared by ER nurses during the shift change. It is intended to contribute to the analysis of the quality of the information shared by nurses during the shift handover, in the emergency service, with a view to the continuous improvement of the quality of care.

\section{Background}

Information sharing is central to delivering health care and promoting customer well-being. Adequate information sharing is key to ensuring quality and continuity of care. According to Sousa (2006), the information includes a set of data, arranged in a useful and meaningful context that, when provided in a timely and suitable manner, provides guidance, instructions, and knowledge to its receiver, which helps with decision-making in a given context. Mota (2010) emphasizes that information influences decision-making, both at a clinical, organizational, or management level. Therefore, there is a great concern to ensure that the information is accurate and reliable, as the continuity of care depends heavily on the quality of the exchange of such data.

Information sharing can be seen as the exchange of information between professionals in the same field, the same service, or in the interlinkage between different services and institutions (Sousa, 2006). According to Hayrinen et al. (2008) as cited in Mota (2010), the continuity of care depends fundamentally on the quantity and quality of information produced by the nurses caring for the patient.

The continuity of healthcare services, provided effectively and safely, depends entirely on the existence of efficient communication mechanisms among the team members, while shift handover is a pivotal moment when accurate information on the patient concerning care health, treatments and services, current status and all recent or planned changes is exchanged (World Health Organization, 2007). Consequently, as stated in the Code of Ethics for Nurses (Ordem dos Enfermeiros, 2015), nurses must ensure continuity of care by keeping reliable records of observations and interventions. 
The concept of change of shift has evolved, and is currently perceived as the sharing of information that takes place after the delivery of healthcare to patients, thus providing a privileged moment for thinking about the continuation of the care delivered to the patient (Manser, Foster, Gisin, Jaeckel, \& Ummenhofer, 2010). According to Nunes, Amaral, and Gonçalves, (2005, p. 231) "the change of shift is when the team of nurses meets to ensure the continuity of care by exchanging information verbally, to promote the continuous improvement of the quality of care."

As Jorm, White, and Kaneen (2009) report, it is vital that nurses recognize the importance of the change of shift as key to delivering safe and quality care. In order for the handover to be efficient and to fulfill its objectives, the exchange of information must follow fundamental criteria. In other words, it must be answer all questions asked until all elements involved in the exchange of information have been fulfilled, concise, including only relevant statements and avoiding unnecessary repetition, concrete, taking into account that the words used should not have a double meaning, being specific and carefully considered, clear, where short, familiar words are used to build understandable, effective and accurate messages, with the appropriate language for the relevant circumstances (Victorian Quality Council [VQC], 2010).

Nursing is a science based on human interaction, consisting of a remarkable wealth of information. Therefore, it is crucial to reflect on the content of this information that is seen as the basis of human communication (Pereira, 2009).

One of the challenges for nurses is the decision on which information they must share with the other nurses. In some cases, nurses tend to convey too much information, while other nurses exchange insufficient, irrelevant, and unnecessary information or overlook important aspects. The development of standardized communication tools aims to bridge the identified gap regarding the lack of formal structure and guidelines that help the professional to organize the information (Jorm et al., 2009). In this way, the Directorate-General for Health (Direção - Geral de Saúde [DGS], 2017) advocates the use of the ISBAR technique - which is a simple, clear and concise acronym in which each letter is a stage: I - identify, S - situation, B - background, A - assessment, $\mathrm{R}$ - recommendation, with the aim of promoting patient safety in the transition of care, providing for efficient communication.

The emergency service is patients' doorway to the hospital environment, impacting significantly patient satisfaction at their state of health/illness. Nursing in the emergency service features a diversity of knowledge, patients and health/disease status, and involves systematic practice, including the nursing process and diagnosis, decision-making, scientific, analytical and research thinking (Patrick, 2011). The purpose of the emergency service is to receive, diagnose, and treat injured patients with sudden or chronic illnesses who require immediate medical care (Administração Central do Sistema de Saúde, 2015).

Nurses are central to healthcare, assuming a vital role in the continuity of care since they are the ones who spend the most time with the patient. The changing of the nursing shift in the emergency service has been discussed over time, especially at the international level. However, at the national level, it is noted that research is still at an early stage.

\section{Research question}

What is the content of information shared by nurses in the emergency service that is relevant for ensuring the quality care and patient safety as a guarantee of continuity of care?

\section{Methodology}

A qualitative exploratory study was drawn up, using the focus group technique as the data collection strategy. This technique was chosen to acquire several perspectives on the theme under study, fostering the discussion among the participants, and encouraging them to support their opinions. The focus groups addressed issues on the relevance of information exchanged between nurses during the shift handover, to ensure safety, fostering the continuity of quality care and excellence.

The focus group was attended by nurses who had been identified by their peers as experts in 
the emergency area, that is. With more than 8 years of professional experience in the emergency service or with leadership or coordination positions in the team. According to Nunes (2010), an expert is someone whose knowledge and training in a given area is acknowledged from both a scientific and practical perspective, taking into account their professional expertise. The sample was intentional, with the heterogeneity of sexes, ages, and professional experience. An invitation was addressed by email at nurses who work in the emergency service and fulfilled the pre-set requirements of experts.

Two focus groups were conducted in order to compare different realities and perceptions about the topic, thus enabling the gathering of a broader set of data. Each group was asked clear and open questions on the topic at hand, which they discussed amongst themselves and analyzed the respective findings.

The first focus group was held on January 31, 2018 , at 3:00 p.m. It was composed of seven nurses working in the emergency services of hospitals in the northern region of mainland Portugal, all of whom were nursing specialists and had from 8 to 23 years of professional experience. The second one took place in the Autonomous Region of the Azores, on February 8,2018 , at 3:00 p.m. It included six nurses with 8 to 29 years of practice experience, all of whom had team coordination functions. The average duration of each focus group was about 60 minutes.

Subsequently, the complete transcription of the recordings was done, and a code was assigned to each participant for anonymity. In the discussion of the results, the focus group held in mainland Portugal is referred to as FC and the focus group of the Autonomous Region of the Azores as FA. A number was also assigned to each participant. Data were analyzed according to the Bardin (2015) content analysis method, without prior categories. The data was processed manually by the researchers, who looked into the teams' views on the set research topics and listed in the results section.

Audio recordings of the focus groups' discussion were made, to analyze them later, having ensured the confidentiality and anonymity of the participants, who gave their free and informed consent. Participants were free to leave the study at any time. The study was authorized by the Ethics Committee of the Higher School of Health of the North of the Portuguese Red Cross under the study identification number E26042018 and opinion number 19.

\section{Results and Discussion}

Shift change of nurses provides a unique opportunity for the exchange of information that ensures the continuity of excellent care. It is considered one of the most important health practices, and one that has the greatest potential for fostering the commitment to patient safety. The importance of handing over the shift for patient safety is an international concern and is essential for the continuous delivery of safe care (Thomson, Tourangeau, Jeffs, \& Puts, 2017). Both groups were sensitive to the importance of information exchange during a shift change, but they realized that this is not ideal and can be improved.

From the analysis of the data, four categories were drawn: Patient information, Health status development, Type of communication, and Constraints of the shift handover. Some of these categories were subdivided to facilitate analysis and understanding of the data.

\section{Patient Information}

This category was subdivided into the following subcategories: Patient identification, Personal history, Out-patient medication, and Reason for returning to the emergency service.

Regarding patient identification, both groups emphasized its importance. FC3 states that "we always identify the patient by their name" (January 2018) although they also say that sometimes this identification is eliminated and replaced by the bed number. FA1 mentions that "information on the patient's civil identification" should be transmitted (February 2018). The shift change must include a set of information that is essential for identifying the patient and should follow a set sequence. In addition to highlighting the importance of personal data, FA4 reinforces the importance of exchanging information about the health history, "patient's age, background" (February 2018) and FC3 adds, "we state the patient's prior history, if he is hypocoagulated, if he had fracture a month ago "(January 2018). Along 
the same line of thought, FA1 underscores further that "the medication that the patient takes at home" (February 2018) should also be exchanged.

Finally, FC and FA were consistent regarding the exchange of information about the reason for returning to the emergency service, highlighting its importance, "we refer that he came here for this and that", "reason for admission", "we identify the cause for admission"," what brought him here" (January and February 2018).

All of this information is in line with what the DGS (2017) underscores as patient information that must be shared in the shift change, stating that this should be based on the personal data of the patient concerned. The same author also reinforces the description of the current reason for requiring healthcare, as well as personal history.

\section{Health status development}

In this context, the subcategories are: Medication, Vital signs, Complementary diagnostic tests, Implemented interventions, and Complications.

The FC sample claims that it is important to pass on information about "admission, screening, clinical assessment, and complementary diagnostic tests, what has been done and what remains to be done" (January 2018). Klim, Kelly, Kerr, Wood, and McCann (2013) reinforce the importance of conveying critical information about treatments performed, relevant nursing observations, and care plan. When the shift is handed over, information that facilitates the decision-making process for the nurse, concerning the nursing care needs of the patient and the medical treatment implemented, must be exchanged.

Concerning vital signs and medication administered in the emergency service, FC4 highlights transmitting "vital sign monitoring every $\mathrm{X}$ hours" (January 2018) and FC3 adds "whether therapy was effective or not” (January 2018), emphasizing the importance of referring to its effectiveness.

Regarding this category, the FA focus group reveals that nurses must be aware of all the dimensions arising from the developments in the patient's health status (February 2018). FA6 says that "all information must be shared" (February 2018). Emphasizing the efficacy of therapy, FA3 mentions that information must focus on the "key point of all our actions, the effectiveness of therapy" (February 2018). The two groups share the same opinion, in line with the assumptions of Klim et al. (2013), who emphasize the importance of exchanging information on vital signs and therapy delivered in the emergency service.

In this subcategory, the importance of passing information about treatments that require more vigilance is highlighted, as referred by FC4, "whether or not blood derivatives were administered" (January 2018) and by FC7, "information on therapy, if there are more doses, the frequencies of the following doses, what are the results "(January 2018). FA1 points out, about this, that "Patients who have more records need more vigilance" (February 2018). It is recommended to provide information about the patient's progress, plan of care, prognosis and significant clinical condition changes, as well as the outcome of complementary diagnostic tests. According to The Joint Commission International (2007), the information exchanged should include developments in the health status of patients, the treatment administered, and the adverse effects and complications. FC7 mentions "autonomous interventions requiring planning, patient status, patient stability, diet, if the patient is fasting" (January 2018), while FC5 adds "notice that the patient is getting macerated skin, or even that patient is aggressive or might try to run away or may fall"(January 2018). While the FA sample reinforces the importance of transmitting care priorities based on "the information gathered, it draws up its care plan and priorities" (FA2; February 2018).

In summary, the DGS (2017) stresses that the change of shift should focus on information on patient status, drug and non-drug therapy prescribed, treatment strategies, significant changes in health status, description of appropriate behavior and the therapeutic plan adjusted to the clinical situation of the patient.

\section{Type of communication}

According to the analysis of the results, the type of communication influences to a large extent the efficiency of the shift handover, since ineffective communication can lead to omissions or inconsistencies in shared information, 
jeopardizing patient safety.

Both groups share the same view on the type of communication used to change shift, stating that this should be "the most concise and most important," "synthetic" (FC3, January 2018). In turn, in the second group, FA2 reinforces that "only pertinent information should be exchanged" (February 2018), as described by the VQC (2010).

The major difference between the two focus groups is how information is recorded; the FC records on electronic media and paper, while the FA only produces paper records. In relation to the impact of these records on the sharing of information, FC7 states that "it must be written and supported by the computer panel adapted to the reality of the emergency service" (January 2018) and the FA3 shares the same opinion by stating that "we have the process for looking up information at any time "(February 2018). According to Klim et al. (2013), to avoid communication gaps during the change of shift, this should be based on the patient's clinical file to ensure accuracy and consistency. Although the groups focus on the importance of nursing records for continuity of care, they point out that there are often gaps in these records for all sorts of reasons. As FA2, FA3 and FA4 highlight, "we share more verbally than using written means" (February 2018) and FC5 underscores, "we convey much more verbally than through writing" (January 2018). The shift change must include a set of information that is essential and should follow a set sequence. The FC7 agrees with this idea and emphasizes that "systematization and methodology are positive as they avoid free will, and ensures systematized and quality records that then provides for a good change of shift" (January 2018). FA2 and FA5, in turn, state that "standardization promotes patient safety" (February 2018). Kerr, Klim, Kelly, and McCann (2016) point out that an organized shift change helps reduce error in the exchange of information, making it more consistent and accurate.

It is recommended that the sharing of information be clear, without ambiguity, in order to avoid confusion in the people that receive it. Thomson et al. (2017) emphasize the importance of implementing protocols and developing communication strategies, such as the use of standardized mnemonic instruments to guide information sharing, leading to significant improvements in communication.

\section{Constraints in shift change}

Although this topic is not the object of our study, it is pointed out by the participants as having an impact on the effectiveness of the shift handover, as it impacts the quality of the content of the information exchanged. This category has been divided into the following subcategories: Empathy/respect, Place of shift change, and Duration of shift change.

FC4 finds that "the effective shift change takes place with the people we empathize least with, while with colleagues we empathize with most we ramble and risk losing important information" (January 2018). FA2, in turn, states that "it is a question of respect, not confusing an empathic relationship with a relationship of friendship" (February 2018). Thomson et al. (2017) argue that empathic relationships with colleagues influence communication during the shift change positively. In this respect, our sample differs from scientific evidence, as it highlights the negative aspects of the exchange of information between nurses who feel greater empathy, as they may trivialize the moment. Concerning the best place for handing over the shift, our sample agrees that it should not take place by the patient. FC3 alleges that it "is not good for the patients, because they become suspicious, patients interrupt us, we lose our train of thought" (January 2018). FA6 also agrees that "there are things we say to the patient that can be misinterpreted by him" (February 2018). FC7 emphasizes that "it should be a reserved and private location" (January 2018). Kerr et al. (2016) point out that the shift change should take place with the patient so that they can participate in their care management and decision-making. However, the same author raises questions regarding the confidentiality of the data and patient privacy.

Concerning the duration of the shift handover, FC7 emphasizes that "the change of shift should not take too long, as it affects concentration and causes distraction; 15 to 20 minutes should be enough for hand over the shift" (January 2018). FA1 agrees, "a longer shift change causes some annoyance and distractions, it requires much concentration, in shorter shift changes 
information is exchanged with more accuracy. ... the information is more useful" (February 2018). Shift changes are usually time-consuming and tiring, leading to the trivialization and futility of the information exchanged. Klim et al. mention that the exchange of information can be extensive and inconsistent and may hurt the continuity of care.

Concerning the specificities of the emergency services, FC4 says that there are "many patients in the service and we cannot even prepare a suitable shift change, and there is a disparity of caregivers, not everyone is putting the same care into keeping records" (January of 2018). Participants of the FA group did not mention this aspect, as their reality is different; they are smaller and have fewer patients. Thomson et al. (2017) emphasize as characteristics that hinder the shift handover in the emergency service the fact that the service is chaotic and erratic in nature, the patient turnout is irregular, the pace of work is accelerated, constant surveillance, physical overload, several caregivers for a single patient, in addition to high patient movement. In short, in order for the change of shift to be effective and help improve patient care and safety, it must follow guidelines that safeguard against omission or ambiguity of data.

\section{Conclusion}

Nurses are aware of the importance of the exchange of information during the change of shift and realize that it can be improved. Thus, information on patient identification, current situation, pertinent information, health history, care provided, and care plan should be shared when the shift is handed over. Such exchange of information is constrained by several factors, which may influence continuity of care positively or negatively, such as the type of communication, duration, and place of shift change, empathy, and respect.

The study was faced with some constraints concerning the lack of homogeneity of the sample, as one of the groups had specialized nurses and the other had only general care nurses due to the reduced number of specialists in the Autonomous Region of the Azores, the size and characteristics of the emergency service, as well as the turnout of patients.
The acknowledgment of the content of information exchanged between nurses in the emergency service makes it possible to streamline communication processes among professionals from the same area, although there is the need to prioritize the information by levels of importance. This study allowed us to produce data and an answer to our research question. However, we consider it important to continue developing this topic, addressing the value of information and the possibility of it being reproduced quantitatively.

Ineffective exchange of information during the change of shift is a global concern, and nurses need to be encouraged to understand the quality of the information shared and its importance for the continuity of optimal care.

\section{References}

Administração Central do Sistema de Saúde. (2015). Recomendaçôes técnicas para serviços de urgências ( $N^{o}$ $R T$ 11). Retrieved from: http://www2.acss.min-saude. pt/Portals/0/Urg\%C3\%AAncias_\%20final.pdf

Bardin, L. (2015). Análise de conteúdo. Lisboa, Portugal: Ediçôes 70.

Direcção-Geral da Saúde. (2017). Norma no 001: Comunicação eficaz na transição de cuidados de saúde. Retrieved from: https://www.dgs.pt/directrizes-da-dgs/ normas-e-circulares-normativas/norma-n-0012017de-08022017.aspx

Friesen, M., White, S., \& Byers, J. (2008). Handoffs: Implications for nurses. In R. G. Hunghe (Ed.), Patient safety and quality: An evidence-based handbook for nurses (pp. 285-332). Retrieved from: https://www.ncbi.nlm. nih.gov/books/NBK2649/

Jorm, C., White, S., \& Kaneen, T. (2009). Clinical handover: Critical communications. The Medical Journal of Australia, 190(11), 108-109. doi:10.5694/j.1326-5377.2009. tb02613.x

Kerr, D., Klim, S., Kelly, A. M., \& McCann, T. (2016). Impact of a modified nursing handover model for improving nursing care and documentation in the emergency department: A pre-and post-implementation study. International Journal of Nursing Pratice, 22(1), 89-97. doi:10.1111/ijn.12365

Klim, S., Kelly, A. M., Kerr, D., Wood, S., \& McCann, T. (2013). Developing a framework for nursing handover in the emergency department: An individualised and systematic approach. Internacional Journal of Nursing Pratice, 22(15-16). 2233-2243. doi:10.1111/jocn.12274 
Manser, T., Foster, S., Gisin, S., Jaeckel, D., \& Ummenhofer, W. (2010). Assessing the quality of patients handoffs at care transitions. British Medical Journal, 19(6), e44. doi:10.1136/qshc.2009.038430

Mota, L. (2010). Sistemas de informação de enfermagem: Um estudo sobre a relevância da informação para os médicos (Dissertaçáo de mestrado). Universidade do Porto, Faculdade de Medicina, Portugal. Retrieved from: https:// repositorio-aberto.up.pt/bitstream/10216/55361/2/ TeseLilianaMotaMIM.pdf

Mota, L., Pereira, F., \& Sousa, P. (2014). Sistemas de informação de enfermagem: Exploração da informação partilhada com os médicos. Revista de Enfermagem Referência, 3(1), 85-91. doi:10.12707/RIII12152

Nunes, L. (2010). Do perito e do conhecimento em enfermagem: Uma exploração da natureza e atributos dos peritos e dos processos de conhecimento em enfermagem. Revista Percursos, 17, 3-9. Retrieved from: https://comum.rcaap.pt/bitstream/10400.26/9215/1/ Revista\%20Percursos\%20n17_Do\%20perito\%20e\%20 do\%20conhecimento $\% 20 \mathrm{em} \% 20$ enfermagem.pdf

Nunes, L., Amaral, M., \& Gonçalves, R. (2005). Código deontológico do Enfermeiro: Dos comentários à análise de casos. Lisboa, Portugal: Ordem dos Enfermeiros. Retrieved from: https://www.ordemenfermeiros.pt/media/8889/ codigodeontologicoenfermeiro_edicao2005.pdf

Ordem dos Enfermeiros. (2015). Código deontológico do enfermeiro. Lisboa, Portugal: Autor.
Patrick, V. (2011). Enfermagem de urgência: Uma visão histórica. In P. K. Howard \& R. B. Steinmann (Eds.), Sheehy enfermagem de urgência: Da teoria à prática (6a ed., pp.3-8). Loures, Portugal: Lusociência.

Pereira, F. (2009). Informação e qualidade do exercício profissional dos enfermeiros. Coimbra, Portugal: Formasau.

Smeulers, M., Tellingen, V., Lucas, C., \& Vermeulen, H. (2012). Effectiveness of different nursing handover styles for ensuring continuity of information in hospitalised patients. The Cochrane database of systematic reviews, 6, CD009979. doi:10.1002/14651858.CD009979

Sousa, P. (2006). Sistema de partilha de informação de enfermagem entre contextos de cuidados de saúde: Um modelo explicativo. Coimbra, Portugal: Formasau.

World Health Organization. (2007). Communication during patient hand-overs. Patient Safety Solutions, 1(3). Retrieved from: http://www.who.int/patientsafety/ solutions/patientsafety/PS-Solution3.pdf

Thomson, H., Tourangeau, A., Jeffs, L., \& Puts, M. (2017). Factors affecting quality of nurse shift handover in the emergency department. Journal of Advanced Nursing, 74(4), 876-886. doi:10.1111/jan.13499

Victorian Quality Council. (2010). Promoting effective communication among healthcare professionals to improve patient safety and quality of care. Melbourne, Australia: Hospital and Health Service Performance Division/ Victorian Government Department of Health. 